\title{
Analysis of Carbon Tax on Selected European Countries: Does Carbon Tax Reduce Emissions?
}

\author{
Ali Eren Alper \\ Correspondence: Ali Eren Alper, F.E.A.S., Nigde Omer Halisdemir University, Nigde, 51240, Turkey.
}

Received: November 14, 2017

doi:10.11114/aef.v5i1.2843
Accepted: December 3, $2017 \quad$ Available online: December 4, 2017

URL: https://doi.org/10.11114/aef.v5i1.2843

\begin{abstract}
Since the first days of its existence, the humanity had been using natural resources to meet its needs. Especially along with the globalization period as a result of the Industrial Revolution and the rapid development of communication technologies within the last fifty years, the production has increased significantly in the world and has created negative effects on the environment. The leading adverse effects involve the emission of greenhouse gases and the global warming, which stem from the energy supply of fossil fuels as the main inputs of production. The global warming can be described as an increase in temperature worldwide. Irreversibility is the most important feature of the global warming. Therefore, in the absence of objective measures, the future costs would be much higher than the current ones. For this reason, governments need to take various measures to reduce the volume of emissions. The most important of these measures is carbon taxes. Carbon taxation encourages individuals to use fewer fossil fuels and to find new sources of energy by increasing the cost of using fossil fuels that cause carbon dioxide emissions through the price mechanism. To this end, the impacts of carbon tax levied in 18 selected European countries on economic growth, urbanization, natural gas and petroleum usage, and $\mathrm{CO}_{2}$ emissions are examined by panel data analysis for the 1995-2015 period. The analysis results indicate that a $1 \%$ increase in environmental taxes reduces carbon dioxide emissions by $0.9 \%$. Furthermore, it is reported that a $1 \%$ increase in natural gas and petroleum consumption among the variables included in the analysis increased carbon dioxide emissions by $0.1 \%$ and $0.7 \%$, respectively; while a $1 \%$ increase in urbanization reduced carbon dioxide emissions by $0.9 \%$.
\end{abstract}

Keywords: carbon tax, emission, panel data

\section{Introduction}

Since the dawn of the history, natural resources had been used to meet the needs of mankind. However, the effects of unconscious consumed natural resources and pollution have begun to be felt even more within the last century. The Industrial Revolution was the main cause of these changes experienced throughout the last century. Being considered to be the most appropriate sources for meeting the gradually increasing energy demand throughout the decades since the Industrial Revolution, fossil fuels had been intensively used.The increase in the release of carbon dioxide gas resulting from the use of fossil fuels has destroyed nature more and more every day.

Destruction of nature has become the problem of the whole mankind along with the globalization phenomenon that emerged as a consequence of rapid development in communication and transportation technologies since the second half of the $20^{\text {th }}$ century. These problems, which threaten individuals and countries, are the environmental pollution involving all land, air and sea areas of the world, ozone layer thinning, global warming and climate change, reduction of biological diversity, epidemics, wars, and migrations.

Those affected by these changes are not merely living things. Economic actors can also be affected either positively or negatively by this change. This, in turn, causes the global economy to be affected. According to the "Intergovernmental Panel on Climate Change" (IPCC) Report declared in 2007, crucial measures to be taken against the global warming problem would cost $1 \%$ of global gross domestic product (GDP). Otherwise, $\% 20$ GDP loss would be incurred.

The global warming can be described as an increase in temperature worldwide. The IPCC Report stated the existence of a close relationship between global average temperatures and greenhouse gas emissions. Carbon dioxide $\left(\mathrm{CO}_{2}\right)$ has the biggest share among the greenhouse gases causing the global warming. $\mathrm{CO}_{2}$ gas accounts for the $80 \%$ of the total greenhouse gas emissions (Yavuz, 2014). The main function of the greenhouse gases in the atmosphere is to keep the world temperature at a certain level by preventing a certain amount of solar rays from penetrating through the 
atmosphere. However, since the rate of increase in greenhouse gas emissions is well higher than nature's ability to absorb the emission, it causes the higher density of the greenhouse gases which, in turn, enhance the heat holding ability. As a result, the effect of increasing the earth temperature occurs.

According to the IPCC (2007), an increase of 1.1 to 6.4 degrees in the global temperature would cause 16.5 to $53.8 \mathrm{~cm}$ rise at sea level as of the year 2100. According to Tiwari (2011), the consequences of global warming due to greenhouse gas emissions would be subject to change depending on the social and natural characteristics of the countries. According to Stern et al. (2006), this radical global temperature change would affect all countries, but the earliest and harshest impact would emerge in poor and crowded countries among others. According to Aliusta et al. (2016), global warming is defined as a loss for some businesses and gain for others. Some of these gains and losses are as follows;

- Increased agricultural product prices due to reduced production of agricultural products,

- Decrease in river and canal transportation,

- Increasing health expenditures due to natural pollution,

- Revenue growth in the heating and cooling sector,

- Damages in the insurance sector due to the increase in natural disasters.

The most important feature of global warming is that it cannot be reversible. In the absence of such measures, future costs tend to be much higher than the current ones. Also, it is very difficult to predict future costs. The irreversible feature of global warming calls for aggressive prevention and control mechanisms (uncertainty, low initial cost of control, high costs to be met if it cannot be acted on, and global benefit if it can be controlled) (Pearce, 1991). One of the most important tools used recently to reduce environmental impacts is carbon taxes. The basic assumption about carbon taxes is that the environment would be destroyed by many fossil fuel users in the absence of regulations (Markandya, 1993).

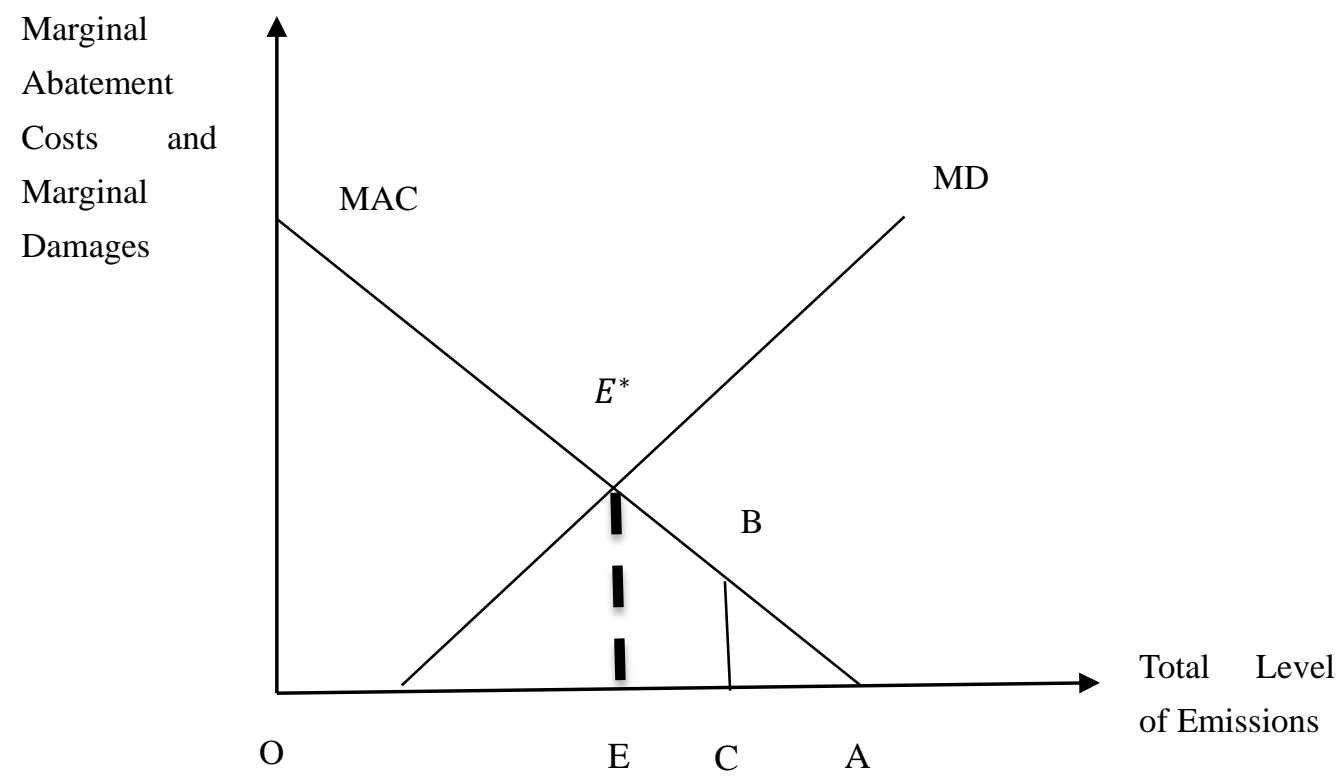

Figure 1. Marginal Cost, Marginal Loss and Optimal Contamination Level

Source: Markandya, 1993, p. 3

The cost of reducing the emission volume is less than the benefit to be achieved when the emission volume is reduced. This situation is shown in Figure 1. The amount of emission and marginal cost/marginal loss are placed in horizontal and vertical axes, respectively. Marginal abatement cost (MAC) refers to the last unit of expenditure made to prevent environmental pollution. This cost can be in the form of investments in cleaner technologies, as well as in the form of the costs of switching from fossil fuels to other cleaner energy sources. The marginal damage (MD) curve is drawn under the assumption that economic actors tend to act in a manner that would minimize the impact of each emission increase on themselves. The MD curve postulated in Figure 1 implies that the reduction in environmental pollution would reduce the expenditure for future environmental improvement. As shown in Figure 1, the optimal level of emission volume is $\mathrm{OE}$ where the MAC and MD curves intersect. Beyond the intersection point, the level of damage to the nature created by an increase in the volume of emissions would be higher than the saving to be achieved from abatement costs.

Therefore, governments need to take various measures to reduce the volume of emissions. The first one of these 
measures, which is essentially a rewarding method, involves financially supported production activities that contain certain technologies. The second one is carbon taxation based on the punishment method. The carbon tax is levied on some $\mathrm{CO}_{2}$ emissions caused by fossil fuel consumption (Al-Abdullah, 1999, p.5). Carbon taxation puts an extra burden on fuel prices, thus promoting the use of alternative cleaner fuels by preventing the use of these fuels by offering a more expensive price to users through public intervention. According to Pearce (1991), the carbon tax has some advantages over the alternative means of regulation, control, and command. These are,

- Most taxes distort incentives; an environmental tax corrects a distortion the externalities arising from the excessive use of environmental services.

- The double dividend feature of a carbon tax could be extremely important in the international context.

- Environmental taxes have the potential to minimize compliance costs for industry, and hence for consumers who will bear some portion of the tax.

- Carbon taxes act as a continuous incentive to adopt cleaner technology and energy conservation.

- Moreover, lastly, carbon taxes can be easily modified as new information comes to light.

The main aim of the study is to investigate the applicability of carbon taxation for sustainable growth regarding raising environmental quality in European countries. For this purpose, the impacts of carbon taxation, economic growth, urbanization, natural gas and petroleum usage on $\mathrm{CO}_{2}$ emissions is examined in 18 selected European countries (Germany, France, Austria, Belgium, Denmark, Finland, Greece, Ireland, Italy, Estonia, Netherlands, Norway, Poland, Spain, Sweden, United Kingdom, Czech Republic, Romania) using panel data analysis for the period 1995-2015. In the second part of the study, the concept of green economy is explained. In the third part, the selected literature review is made. In the fourth part, data set, model and econometric results are forwarded, and in the conclusion part, the study is completed.

\section{Green Economy and Sustainable Development}

The progress of the global economy as a result of the industrialization period which lasted more than 200 years in the Western world more than 50 years in developing countries has a cost involving the global warming, ozone layer depletion, soil erosion, air and water pollution. As a result, in 1987, the Bruntland Report by the United Nations defined sustainable development as "the development of those needs without compromising the ability of future generations to meet their own needs." According to Barbier (2011), the conclusion drawn from the definition of sustainable development is that the consequences of the increase in today's welfare level should not diminish the future prosperity level. In other words, future generations should have at least economic chances provided for the current generation in order to create their own economic welfare.

Despite the initial reluctance of economic actors, today, 95\% of large corporations in Europe and the US believe in the importance of sustainable development. At the 2001 World Economic Forum meeting, the world's leading mining, oil, gas, automotive, chemical and finance companies have become members of the World Business Council for Sustainable Development. The main reason for the increase in interest and support for the concept of sustainable development is the change in the patterns of understanding the relationships between people and nature. For the last few centuries, nature has been described as a resource that must be used as an exogenous element for humanity. Within this period, environmental problems have been regarded as regional. Along with the development of the Industrial Revolution and the modern science, the basic view is that mankind would overcome those problems (Hopwood, 2005). Nonetheless, environmental problems have begun to emerge at an accelerated pace due to the rapid expansion in activity volume and impact of the economic system beyond ecological system's capacity to regenerate itself, and these problems have emerged on a global scale, not a local one. One of the most important indicators of the growing ecological worldwide famine is the Millennium Ecosystem Assessment (2005). Accordingly, as indicated in Table 1, 60\% of the world's major ecosystem goods and services are being degraded or unsustainably used.

Table 1. Global status of key ecosystem goods and services

\begin{tabular}{|c|c|c|}
\hline Condition globally has been enhanced & Condition globally has been degraded & Condition globally is mixed \\
\hline $\begin{array}{l}\text { - Crops } \\
\text { - Livestock } \\
\text { - Aquaculture } \\
\text { - Global climate regulation }\end{array}$ & $\begin{array}{l}\text { - } \text { Capture fisheries } \\
\text { - Wild foods } \\
\text { - } \text { Good fuel } \\
\text { - } \text { Bionetic resources } \\
\text { - } \text { Fredicines } \\
\text { - } \text { Air quality regulation } \\
\text { - Resion regulation } \\
\text { - Regional and local climate } \\
\text { - } \text { Pogulationation }\end{array}$ & $\begin{array}{l}\text { - Timber } \\
\text { - Cotton, hemp, silk } \\
\text { and other fiber } \\
\text { crops } \\
\text { - Water regulation } \\
\text { - Recreation and } \\
\text { ecotourism }\end{array}$ \\
\hline
\end{tabular}


Low-carbon economy, resource efficiency, green investments, technological development, and recycling are the pillars of the strategies to be created for the sustainable development and green economy relationship. The United Nations Secretary-General (2010) summarized the policy strategies that the countries need to implement towards the green economy transition. Accordingly,

- Adjust prices to reflect the internalization of external costs, encourage sustainable consumption.

- Implement tax reforms that support environmentally friendly and sustainable practices.

- Expand public support for sustainable energy efficient infrastructural development.

- Enhance research and development programs focused on green technologies.

- Implement policies that harmonize social goals with existing or future economic policies.

There are three main groups of indicators that need to be considered during the green economy transition process. The first major indicator group is comprised of investment, employment and production indicators in the basic sectors of the green economy. At this point, production volume, employment and investment amounts of renewable energy and waste conversion sectors are considered as important indicators of the green economy transition. The second main group of indicators involves the measurement of how well economic growth and environmental damage are separated from each other. For example, the sources from which the energy used in production are produced, the intensity of raw material usage in the economy and the organizational level of the waste conversion sector are important indicators for the green economy. The third main area of the benchmark, which is considered as an indicator for the green economy transition, is the measurement of economic well-being, poverty and the renewability of natural resources collectively. Because, traditional monetary measurement methods such as GDP do not take environmental pollution into account (Jones, 2011).

Green economy and sustainable development are mutually complementary concepts. The green economy is a concept that clarifies the national and international duties that must be undertaken to achieve sustainable development goals. In many cases, the concept of sustainable development is divided into three parts: economy, environment, and society. These three indivisible sectors are depicted as three interconnected rings shown in Figure 2. Sustainable development is a phenomenon that can be achieved by bringing these three elements together in a balanced way (Giddings et al., 2002).

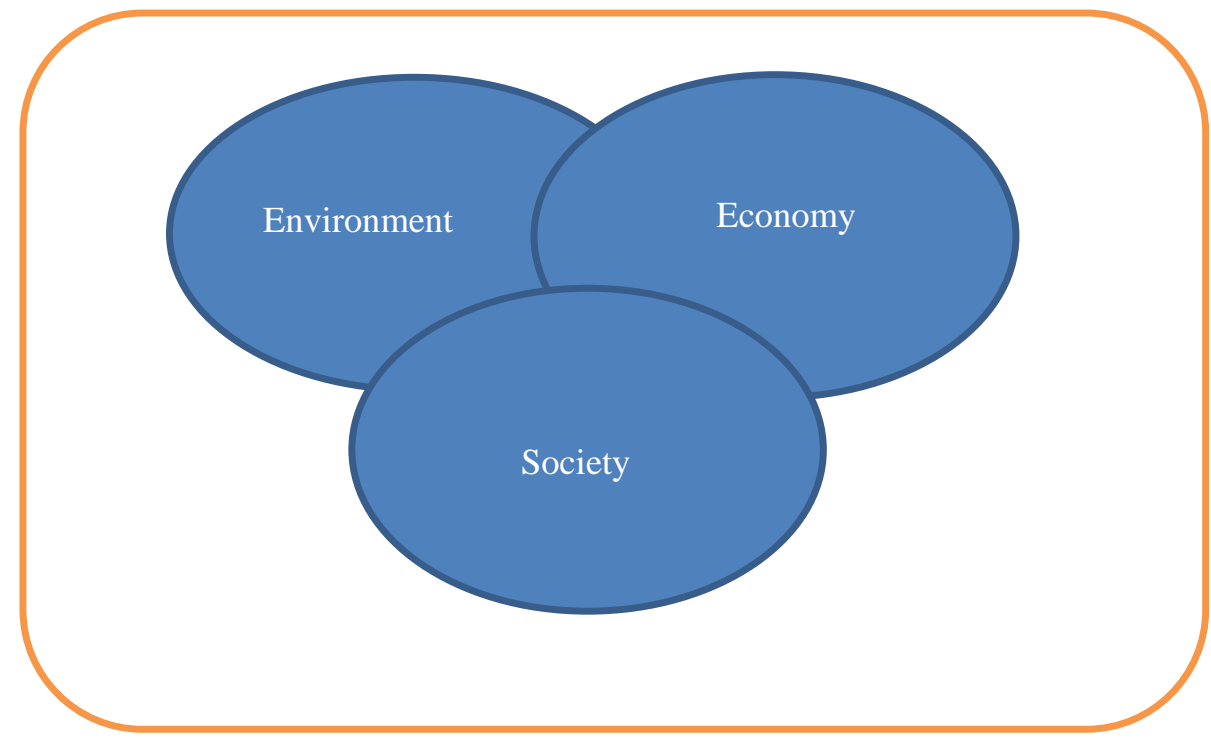

Figure 2. Three ring sector view of sustainable development

Source: Giddings et al., 2002, p. 189.

\section{Selected Literature Review}

Environmental taxes have found a wide application area all over the world, especially in many OECD and European countries. Parallel to this, the intensity of academic studies that investigated the environmental impacts of environmental taxes, especially after the 1990s, has also increased. It is possible to divide these studies into two categories. In the simulation studies, probable environmental effects of environmental taxation that may have been put into practice are estimated, while the effects of environmental taxation experiences are estimated in studies that include many econometric analyses (Topal and Günay, 2017).

Baranzini et al. (2000) argued that carbon taxation must be implemented through a general reform of the financial system. Abolishment of energy subsidies is stated to be one of the foremost reforms. Secondly, the activities that 
increase the environmental pollution are stated to be excluded from the general financial system. Thirdly, carbon tax incomes have to be reintegrated with the decline in other taxes such as income and corporate taxes.

Bruvoll and Larsen (2002) studied the wide-ranging climate policies implemented in Norway over the last decade. Despite this policy, implemented in 1991 by Bruvoll and Larsen (2002) and based on large amounts of carbon taxation, the impacts of carbon taxation on greenhouse gas emissions in Norway are rather low. According to the researchers, the cause of the low impact of carbon taxation is due to the inelasticity of energy demand.

Lin and $\mathrm{Li}$ (2011) have examined the mitigating effects of carbon tax using the difference-in-difference method for 5 Northern European countries. The results indicate that the carbon tax in Finland has a negative effect on the growth of per capita $\mathrm{CO}_{2}$ emissions. The results are also negative but not significant in Denmark, Sweden, and the Netherlands.

Zhao (2011) tested the effects of the carbon tax on energy-sensitive industries using the Gravity model using data obtained from 21 OECD countries between the period 1992-2008. As a result of the research, the study concluded that carbon taxation has a negative impact on the development of the related sectors by creating a competitive disadvantage in industries with higher energy consumption.

Miller and Vela (2013), unlike other studies, have studied the impacts of environmental taxation on different environmental quality indicators assigned to both developed and developing countries separately. For the 50 countries, data obtained between the period 1995-2010 are analyzed by cross-section, panel seemingly-unrelated regression (SUR) and system GMM dynamic panel data methods. According to the results of the study, a robust negative correlation between environmental taxation and carbon emissions is found in all samples. Another consequence of the research study is that carbon tax practices reduce energy usage and increase the preference of renewable resources.

Allan et al. (2014) used a disaggregated energy-economy-environmental model to investigate the economic and environmental of a Scottish specific carbon tax under three alternative assumptions. The results of the model suggest that a carbon tax might simultaneously stimulate economic activity while reducing emissions and thus secure a double dividend, but only for the case in which the revenue is recycled through income tax.

Castiglione et al. (2014), by utilizing the data obtained between the years 1992-2012 from 24 EU countries which are categorized into three groups such as market economies with advanced industrial and services sectors, poorly developed economies and transition economies, examined the effects of production, consumption, environmental quality and government quality on environmental taxation by panel data analysis method for each country group. According to the results of the research study, the environmental tax revenues of the countries are significantly affected especially by the level of development and government quality of the economies.

Guo et al. (2014) examined the extent to which carbon taxes affect China's economy and carbon emissions in accordance with China's input-output tables fort he years 2010, using a generalized equilibrium model. Authors divided energy sectors into eight sub-sectors using energy characteristics to achieve robust results in their analysis. According to the analysis results, a reasonable carbon tax reduces carbon emissions and demand for fossil fuel energy.

Jiang and Shao (2014) examined the distributional effects of carbon taxation and explored their usability in China to reduce carbon emissions. To this end, the distributional effects of carbon taxes on households belonging to various income groups in Shanghai, which is China's most important commercial center, are examined using input-output tables. According to the analysis results, the extensive distributional effects of carbon taxes tend to follow a decreasing trend.

Andersson (2015) studied the impacts of the carbon tax and environmental value added tax levied in 1991 to reduce carbon dioxide emissions in Sweden on carbon dioxide emissions for the period 1990-2005. In the study, where data are analyzed using synthetic control methods, the result claims that the levied carbon tax reduces carbon dioxide emission.

\section{Data Set, Model, Econometric Methodology and Findings}

The study aims to determine whether or not the carbon taxes in practice reduce carbon emissions. To this end, using the data of selected 18 European countries (Germany, France, Austria, Belgium, Denmark, Finland, Greece, Ireland, Italy, Estonia, Netherlands, Norway, Poland, Spain, Sweden, United Kingdom, Czech Republic, and Romania), the impacts of the environmental taxes (ET), use of natural gas (NG) and petroleum (PTR), national income growth (GDP), urbanization (URB) on the level of $\mathrm{CO}_{2}$ emissions are tried to be determined by panel data analysis method for 1995-2015 period.

According to Hsiao (2007), the advantages of panel data analysis are as follows:

- Since it performs with higher degrees of freedom, panel data analysis can give rise to more precise estimates.

- It is more convenient than cross-section or time-series data for studies in which complex human behaviors are analyzed. 
- It is suitable to be utilized, especially in developing countries where the hardship of data-collection is eminent because both the cross-section $(\mathrm{N})$ and the time-series $(\mathrm{T})$ are present and the number of observations is the product of these two dimensions $(\mathrm{N} * \mathrm{~T})$.

- Whenever non-stationary time-series are involved, the distributions of the least squares and maximum likelihood estimators happen to be non-normal. In panel data analysis, however, if the cross-sectional observations are independent, the central limit theorem may suggest that many predictors are subject to asymptotically normal distribution along the cross-sectional units.

For this purpose, the model in Equation 1 is to be estimated.

$$
C O 2_{i, t}=\beta_{0}+\beta_{1} E T_{i, t}+\beta_{2} N G_{i, t}+\beta_{3} P T R_{i, t}+\beta_{4} G D P_{i, t}+\beta_{5} U R B_{i, t}+\varepsilon_{i, t}
$$

Since the panel data analysis method is to be used in the study, the cross-sectional dependence (CSD) between the series needs to be examined first. One of the general assumptions in the panel data models is that the error terms are independent of the units, but it can be seen that the error terms have simultaneous correlation along the cross-section units. In this case, as in the autocorrelation and the heteroskedasticity, it prevents the correlation matrix from being a unit matrix. Therefore, the uncorrelatedness between the units should be tested in the basic hypothesis. For this purpose, Pesaran (2004) CSD, Friedman (1937) CSD, and Frees'(1995) CSD tests are applied in the study. CSD test results are given in Table 2.

Table 2. CSD Test Results

\begin{tabular}{cc}
\hline Test & Test Statistic \\
\hline Pesaran CSD Test & 5.911 \\
\hline Friedman CSD Test & 51.270 \\
\hline Frees' CSD Test & $2.024^{1}$ \\
\hline
\end{tabular}

According to Pesaran CD, Friedman and Frees' Test results, cross-sectional dependence is determined. According to Wald Variance Test and Wooldridge Autocorrelation Test results, both heteroskedasticity and first-degree autocorrelation problems are detected in the series. In the panel data models, the first study conducted by taking the heteroskedasticity, cross-sectional dependence and autocorrelation into account was Parks (1967). Parks then proposed an algorithm based on the feasible generalized least squares (FGLS) method developed by Kmenta (1986). In this approach, the examined model is estimated by the generalized least squares method first, then the residuals are used to test the autocorrelation and heteroskedasticity, and then the generalized least squares (GLS) method is used again for estimation. The panel corrected standard errors (PCSE) method was first coined and developed by Beck and Katz (1995). In the PCSE estimation method, the model can be first estimated by the least squares method. The correct estimates of the standard errors of the estimated coefficients are made using PCSE. If the assumptions are assumed to have autocorrelation, corrections are made using the Prais and Winsten (1954) method. Finally, after correction is made, the panel corrected standard errors are obtained from the residues. As the result of the time series properties of the data by taking the cross-sectional dependence into account, heteroskedasticity- and autocorrelation-resistant FGLS and PCSE estimation results are given in Table 3.

Table 3. PCSE and FGLS Estimate Results

\begin{tabular}{lllll}
\hline & & $P C S E$ & & $F G L$ \\
\hline Variables & Coefficient & $p$-value & Coefficient & $p$-value \\
\hline$E T$ & -0.099 & 0.036 & -0.085 & 0.000 \\
\hline$N G$ & 0.133 & 0.000 & 0.135 & 0.000 \\
\hline$P T R$ & 0.707 & 0.000 & 0.697 & 0.000 \\
\hline$G D P$ & 0.002 & 0.028 & 0.002 & 0.000 \\
\hline$U R B$ & -0.910 & 0.000 & -0.895 & 0.000 \\
\hline
\end{tabular}

\section{Conclusion}

The humanity, ever since it existed, had been using the natural resources to meet its earthly needs. Especially along with the Industrial Revolution and the rapid development of communication technologies in the last fifty years accompanied by globalization, the worldwide production level has increased significantly and created adverse effects on the environment. Emission of greenhouse gases, as the result of the supply of the basic inputs of production such as energy from fossil fuels, is of the first order of importance among these adverse effects.

There are two groups of researchers who interpret the interaction between the economy and the environment as the world economy grows the way it does. The first group consists of those who claim a trade-off between the social

\footnotetext{
${ }^{1}$ At $10 \%$ significance level Frees' Q distribution critical value 0.1231 .
} 
policies and economic growth. The second group of researchers argues that policies are necessary to maintain environmental quality for sustainable economic development.

Since the views of the second group of researchers have gained more weight during the recent period, policy-makers are increasingly interested in environmental taxation to protect the quality of the environment. The main objectives of environmental data are to reduce the economic activities that directly or indirectly pollute the environment and to prevent harm to the environment by encouraging environmentally-friendly production/consumption methods. The most important reason for a carbon tax to be proposed and used, as one of the most crucial environmental taxes, is that it is a market-based tax, and thus by reflecting the cost of abatement to prices false price formations would be eradicated. In this way, carbon taxation encourages individuals to use fewer fossil fuels and find new sources of energy by increasing the costs of using fossil fuels that cause carbon dioxide emissions through the pricing mechanism. Therefore, the carbon tax, which is a consumption tax, provides the internalization of negative externalities caused by the consumption of fossil fuels. To this end, the impacts of carbon taxation, economic growth, urbanization, natural gas use and oil use on $\mathrm{CO}_{2}$ emissions in 18 selected European countries are examined for the period 1995-2015. The analysis results indicate that a $1 \%$ increase in environmental taxes reduces carbon dioxide emissions by $0.9 \%$. Furthermore, $1 \%$ increase in both natural gas and petroleum consumptions increased carbon dioxide emissions by $0.1 \%$ and $0.7 \%$, respectively; while a $1 \%$ increase in urbanization reduced carbon dioxide emissions by $0.9 \%$. The obtained results show that environmental taxation can be used as a tool to protect environmental qualities in selected European countries and to achieve sustainable development. It is also found that the use of natural gas pollutes the environment less than of petroleum and the increase in urbanization also reduces carbon emissions due to the use of traditional energy resources with higher carbon dioxide emissions in rural areas. Also, urbanization is detected to encourage the use of natural gas and similar modern energy resources with lower carbon-emission to decrease carbon emissions.

\section{References}

Al-Abdullah, A. Y. (1999). The Carbon-tax debate. Applied energy, 64(1), 3-13. https://doi.org/10.1016/S0306-2619(99)00105-1

Aliusta, H., Yılmaz, B., \& Kırlıŏlu, H. (2016). Küresel Isınmayı Önleme Sürecinde Uygulanan Piyasa Temelli İktisadi Araçlar: Karbon Ticareti Ve Karbon Vergisi. Uluslararası Yönetim İktisat ve İşletme Dergisi, 30, 382-401.

Allan, G., Lecca, P., McGregor, P., \& Swales, K. (2014). The economic and environmental impact of a carbon tax for Scotland: a computable general equilibrium analysis. Ecological Economics, 100, 40-50. https://doi.org/10.1016/j.ecolecon.2014.01.012

Andersson, J. (2015). Cars, carbon taxes and CO2 emissions. London: Grantham Research Institute on Climate Change and the Environment.

Baranzini, A., Goldemberg, J., \& Speck, S. (2000). A future for carbon taxes. Ecological economics, 32(3), 395-412. https://doi.org/10.1016/S0921-8009(99)00122-6

Barbier, E. (2011). The policy challenges for green economy and sustainable economic development. In Natural resources forum, 35(3), 233-245. Blackwell Publishing Ltd. https://doi.org/10.1111/j.1477-8947.2011.01397.x

Beck, N., \& Katz, J. N. (1995). What to do (and not to do) with time-series cross-section data. American political science review, 89(3), 634-647. https://doi.org/10.2307/2082979

Brundtland, G., Khalid, M., Agnelli, S., Al-Athel, S., Chidzero, B., Fadika, L., \& Singh, M. (1987). Our Common Future, <http://www.un-documents.net/our-common-future.pdf>, 03.10.2016.

Bruvoll, A., \& Larsen, B. M. (2002). Greenhouse gas emissions in Norway: do carbon taxes work? Energy policy, 32(4), 493-505. https://doi.org/10.1016/S0301-4215(03)00151-4

Castiglione, C., Infante, D., Minervini, M. T., \& Smirnova, J. (2014). Environmental taxation in Europe: What does it depend on? Cogent Economics \& Finance, 2(1), 967362. https://doi.org/10.1080/23322039.2014.967362

Frees, E. W. (1995). Assessing cross-sectional correlation in panel data. Journal of econometrics, 69(2), 393-414. https://doi.org/10.1016/0304-4076(94)01658-M

Friedman, M. (1937). The use of ranks to avoid the assumption of normality implicit in the analysis of variance. Journal of the american statistical association, 32(200), 675-701. https://doi.org/10.1080/01621459.1937.10503522

Giddings, B., Hopwood, B., \& O'brien, G. (2002). Environment, economy and society: fitting them together into sustainable development. Sustainable development, 10(4), 187-196. https://doi.org/10.1002/sd.199

Guo, Z., Zhang, X., Zheng, Y., \& Rao, R. (2014). Exploring the impacts of a carbon tax on the Chinese economy using a CGE model with a detailed disaggregation of energy sectors. Energy Economics, 45, 455-462. https://doi.org/10.1016/j.eneco.2014.08.016 
Hopwood, B., Mellor, M., \& O'Brien, G. (2005). Sustainable development: mapping different approaches. Sustainable development, 13(1), 38-52. https://doi.org/10.1002/sd.244

Hsiao, C. (2007). Panel data analysis-advantages and challenges.Sociedad de Estadística e Investigación Operativa, 16(1), 1-22. https://doi.org/10.1002/sd.244

Intergovernmental Panel on Climate Change (IPCC). (2007), Climate Change Synthesis Report 2007, <https://www.ipcc.ch/pdf/assessment-report/ar4/wg3/ar4_wg3_full_report.pdf>, 06.09.2017.

Jiang, Z., \& Shao, S. (2014). Distributional effects of a carbon tax on Chinese households: A case of Shanghai. Energy Policy, 73, 269-277. https://doi.org/10.1016/j.enpol.2014.06.005

Jones, B. (2011). Driving a green economy through public finance and fiscal policy reform. Journal of International Commerce, Economics and Policy, 2(02), 325-349. https://doi.org/10.1142/S1793993311000336

Kmenta, J. (1986). Elements of Econometrics, MacMillan. New York.

Lin, B., \& Li, X. (2011). The effect of carbon tax on per capita CO 2 emissions. Energy policy, 39(9), 5137-5146. https://doi.org/10.1016/j.enpol.2011.05.050

Markandya, A. (1993). Environmental Taxation: A Review of OECD Country Experience and Prospects for Economies in Transition. Harvard Intitute for International Development, Development Discussion Paper No: 471.

Millenium Ecosystem Assessment. (2005). Ecosystem and Human Well-Being: Synthesis. Island Press, Washington, D.C.

Miller, S., \& Vela, M. A. (2013). Are environmentally related taxes effective? IDB Working Paper Series, No. IDB-WP-467.

Parks, R. W. (1967). Efficient estimation of a system of regression equations when disturbances are both serially and contemporaneously correlated. Journal of the American Statistical Association,62(318), 500-509. https://doi.org/10.1080/01621459.1967.10482923

Pearce, D. (1991). The role of carbon taxes in adjusting to global warming. The economic journal, 101(407), 938-948. https://doi.org/10.2307/2233865

Pesaran, M. H. (2004). General diagnostic tests for cross section dependence in panels. CESifo Working Paper, No. 1229.

Prais, S., \& Winsten, C. (1954). "Trend Estimation and Serial Correlation”, Discussion Paper 383. Chicago: Cowles Commission.

Stern, N. H., Peters, S., Bakhshi, V., Bowen, A., Cameron, C., Catovsky, S., \& Garbett, S. L. (2006). Stern Review: The economics of climate change, 30, Cambridge: Cambridge University Press.

Tiwari, A. K. (2011). Energy consumption, CO2 emissions and economic growth: Evidence from India. Journal of International Business and Economy, 12(1), 85-122. https://doi.org/10.2307/2233865

Topal, M. H., \& Günay, H. F. (2017). Çevre Vergilerinin Çevre Kalitesi Üzerindeki Etkisi: Gelişmekte Olan ve Gelişmiş Ekonomilerden Ampirik Bir Kanıt. Maliye Araştırmaları Dergisi, 3(1).

United Nations Conference on Sustainable Development. (2010). Progress to date and remaining gaps in the implementation of the outcomes of the major summits in the area of sustainable development, as well as an analysis of the themes of the Conference. 17-19 May 2010.

Yavuz, N. Ç. (2014). CO2 emission, energy consumption, and economic growth for turkey: evidence from a cointegration test with a structural break. Energy Sources, Part B: Economics, Planning, and Policy, 9(3), 229-235. https://doi.org/10.1080/15567249.2011.567222

Zhao, Y. H. (2011). The study of effect of carbon tax on the international competitiveness of energy-intensive industries: an empirical analysis of OECD 21 countries, 1992-2008. Energy Procedia, 5, 1291-1302. https://doi.org/10.1016/j.egypro.2011.03.225

\section{Copyrights}

Copyright for this article is retained by the author(s), with first publication rights granted to the journal.

This is an open-access article distributed under the terms and conditions of the Creative Commons Attribution license which permits unrestricted use, distribution, and reproduction in any medium, provided the original work is properly cited. 